\title{
Seasonal coefficient of performance for ground source heat pump and groundwater one in Białystok
}

\author{
Andrzej Gajewski ${ }^{1, *}$ \\ ${ }^{1}$ Bialystok University of Technology, Faculty of Civil Engineering and Environmental Engineering, \\ Department of HVAC Engineering, ul. Wiejska 45a, 15-351 Białystok, Poland
}

\begin{abstract}
European Economic Area (EEA) states declare to contain greenhouse gases emissions at $20 \%$ by 2020 , whereas European Union (EU) does $40 \%$ before 2030 , which result in encouragement to apply low-carbon technologies. Coefficient of Performance $(C O P)$ and Seasonal Coefficient of Performance $\left(S C O P_{n e t}\right)$ are obtained using temperature measurement done by The Institute of Meteorology and Water Management - National Research Institute (IMGW-PIB) at the weather station in Bialystok for ten-year period. The first variant is ground source heat pump (GSHP) and the second one is groundwater source heat pump (WSHP) which can be equipped with separating heat exchanger (SHE) optionally. In both cases heat is generated for heating system only. Ground temperature is determined from Baggs (1983) formula using Oleśkowicz-Popiel et. al. (2002) adaptation to Polish climate and substituting the local constants achieved by Biernacka (2010). Water temperature in a groundwater basin is obtained from Kowalski (2007) equation. Estimation is done in each hour of heating season. All COP values are higher than 3.5 required by EU (2013). SCOPnet are as follows: 6.12, 5.86, 5.03 for WSHP, WSHP+SHE, GSHP respectively. Insomuch as WSHP needs only two boreholes it is recommended to the areas beneath ones a groundwater basin is located.
\end{abstract}

\section{Introduction}

Continuous temperature measurement since half of $19^{\text {th }}$ century led into conclusion about climate changes on the Earth. It is commonly assumed the reason of temperature increase is in greenhouse gases (methane, carbon dioxide, water vapour, ozone, nitrous oxide, halogenated hydrocarbons, etc.) emissions. There are either natural or anthropogenic sources of these gases. It is supposed that carbon dioxide contribution in temperature rise is between $9 \%$ and $26 \%$. Moreover Keeling Curve indicates higher carbon dioxide concentration from $316 \mathrm{ppm}$ in 1960 to $385 \mathrm{ppm}$ in 2010 at Mauna Loa Observatory (Hawaii) [1]. These observations lead 27 countries to sign a protocol to limit greenhouse effect (the protocol was ratified by Poland on 2 December 2002). Inasmuch as the agreement was concluded in Kyoto, on 11 December 1997, it is known as Kyoto Protocol. After expiry date of Kyoto Protocol

\footnotetext{
*Corresponding author: a.gajewski@pb.edu.pl
} 
which was on $31^{\text {st }}$ December 2012, the states joined in European Economic Area agreed to limit greenhouse gases emissions by at least $20 \%$ of the 1990 levels before the year 2020 . European Commission submitted a conception of 2030 climate and energy framework which includes targets for reducing greenhouse gases emissions by at least $40 \%$ before 2030 and encourages to apply low-carbon technologies [2].

The aim of the paper is estimation of seasonal coefficient of performance for ground source heat pump and groundwater source heat pump. Assessment is based on meteorological measurements conducted by The Institute of Meteorology and Water Management - National Research Institute (IMGW-PIB) at the weather station in Bialystok in the years 2003-2012.

\section{Computation}

Computing is used to the indication of more efficient lower heat source for heat pump which supplies heat for commercial building with total design heat load $Q_{d}=92.73 \mathrm{~kW}$ which is located close to the northern border of Białystok. There are following input: external design temperature $t_{e}=-22^{\circ} \mathrm{C}$, internal one $t_{i}=20^{\circ} \mathrm{C}$, design inflow temperature in heating system is at $55^{\circ} \mathrm{C}$. Since, instant electric water heaters warm tap water to domestic heat water a heat pump unit supplies heat only to the radiators. Insomuch as the building is supposed to be constructed on a location which is situated about $100 \mathrm{~m}$ above major groundwater basin 218 [3] water to water heat pump is considered as the second heat generator for the building.

Estimation of seasonal coefficient of performance $\left(S C O P_{n e t}\right)$ is based on external temperature measurements done by IMGW-PIB at the weather station in Białystok. The temperature data are taken from $1^{\text {st }}$ January 2003 to $31^{\text {st }}$ December 2012. Applying these data mean temperature in each hour in Julian year (that lasts 365,25 days i.e. 8766 hours) is calculated, the results are plotted in Fig. 1 as "external temperature". These mean values rounded to one decimal place are used as bin temperature $t_{j}$ in further calculations.

The evaluation is done for every hour in heating season which lasts from $21^{\text {st }}$ September to $10^{\text {th }}$ May. If amid investigated hour $h_{j}$ heat pump should supply heat current heat load $P_{h}\left(t_{j}\right)$ is determined:

$$
P_{h}\left(t_{j}\right)=Q_{d} \frac{t_{i}-t_{j}}{t_{i}-t_{e}} \quad[k W]
$$

Heating system stops whenever external temperature $t_{j}$ is $15^{\circ} \mathrm{C}$ at least and then $P_{h}\left(t_{j}\right)=0$. Since flow temperature is adjusted by a weather compensator along a curve with exponent 0.6 the curve is approximated by quadratic equation. Temperature in the heating system changes along the curve but in cannot be less than $35^{\circ} \mathrm{C}$ to provide at least $10^{\circ} \mathrm{C}$ temperature difference between the radiator and the room. As a result we obtain heating system temperature dependence on external temperature:

$$
\left\{\begin{array}{lr}
t_{f}=-0.0049 t_{j}^{2}-0.5794 t_{j}+33.602 \quad\left[{ }^{\circ} \mathrm{C}\right] & \text { for } t_{j} \leq-2.5^{\circ} \mathrm{C} \\
t_{f}=35^{\circ} \mathrm{C} & \text { for } t_{j}>-2.5^{\circ} \mathrm{C}
\end{array}\right.
$$

According to EN 14825:2016 SCOP ${ }_{\text {net }}$ is calculated as follows:

$$
S C O P_{n e t}=\frac{\sum_{j=1}^{n} h_{j}\left[P_{h}\left(t_{j}\right)-\sup \left(t_{j}\right)\right]}{\sum_{j=1}^{n} h_{j}\left[\frac{P_{h}\left(t_{j}\right)-\sup \left(t_{j}\right)}{C O P_{b i n}\left(t_{j}\right)}\right]} \quad[-]
$$


where:

$\sup \left(t_{j}\right)$ is the required capacity of an fossil fuel backup heater for corresponding temperature $t_{j}[\mathrm{~kW}]$, $\mathrm{COP}_{\text {bin }}\left(t_{j}\right)$ means coefficient of performance at bin temperature $t_{j}[-]$.

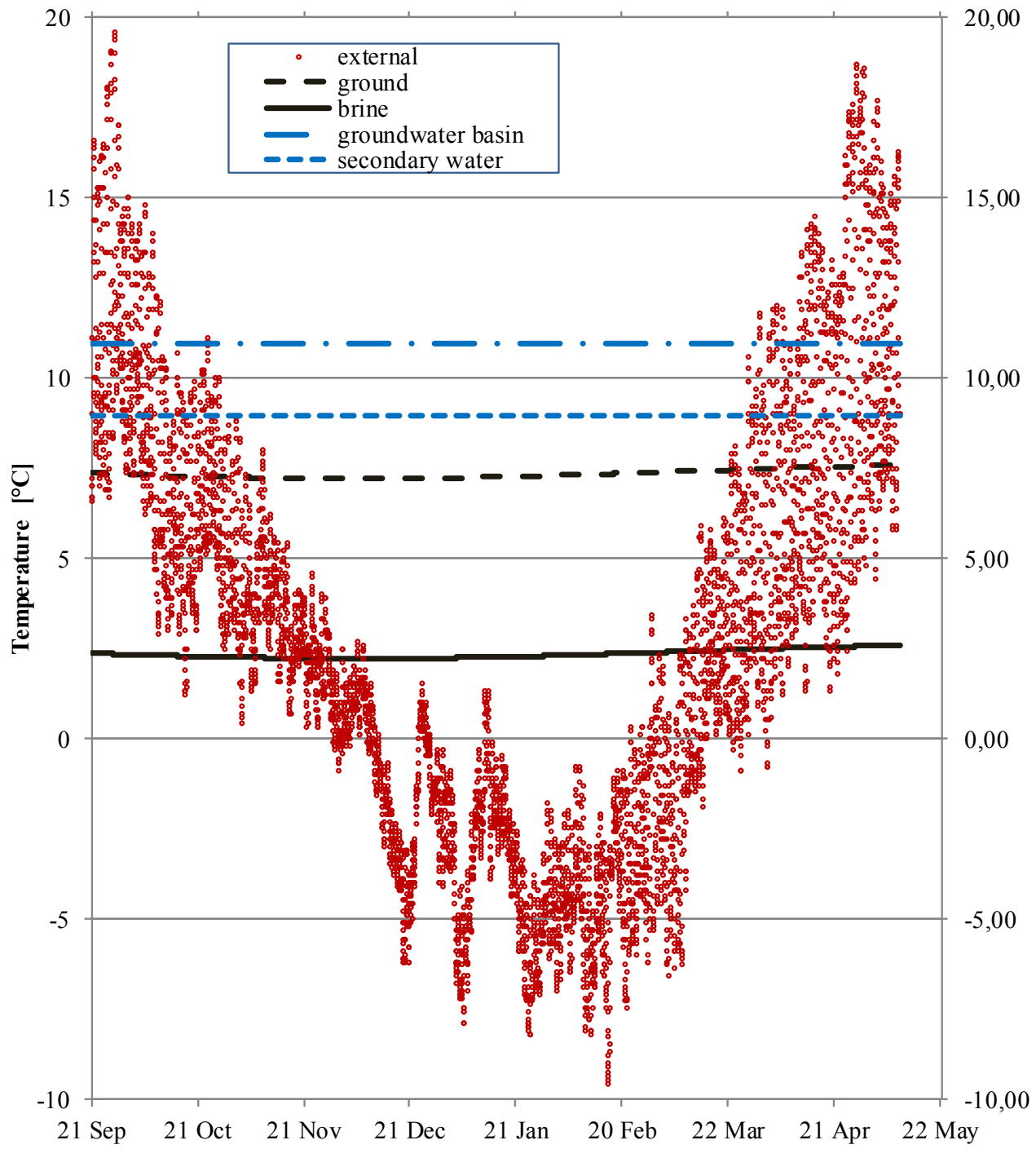

Fig. 1. Hourly temperature changes along average heating season: mean external temperature, ground and brine temperature for GSHP calculations, groundwater basin temperature for WSHP calculations and secondary water temperature for WSHP+SHE calculations.

Inasmuch as heat pump unit is greater than $50 \mathrm{~kW}$ it must be equipped with buffer tanks with capacity $V=2000 \mathrm{dm}^{3}$, thus heat pump unit warms water in buffer tanks to temperature obtained from heating curve (2). Heat pump works when temperature in buffer tanks $t_{t}$ is lower at least $4^{\circ} \mathrm{C}$ than $t_{f}$, which prevents to turn on heat pump for short time period. Hence, the procedure of buffer tanks performance and ones' efficiency of energy storage $\eta_{t}=98 \%$ is included into analysis. To proper estimate buffer tank charging and discharging processes 
amid heating season the calculations are done as follows. Thus ones differ from EN 14825:2016.

Heat losses of buffer tanks $Q_{j}$ are obtained from formula

$$
Q_{j}=\left[i_{j-1}-i\left(20^{\circ} \mathrm{C}\right)\right] \rho_{j-1} V\left(1-\eta_{t}\right)[k J]
$$

where:

$i_{j-1}$ - specific enthalpy of water in buffer tanks in previous hour $[\mathrm{kJ} / \mathrm{kg}]$,

$i\left(20^{\circ} \mathrm{C}\right)$ - specific enthalpy of water in buffer tanks at room temperature $[\mathrm{kJ} / \mathrm{kg}]$,

$\rho_{j-1}-$ water density at temperature in previous hour $\left[\mathrm{kg} / \mathrm{m}^{3}\right]$.

Then, we can establish temperature in buffer tanks in given hour $t_{t j}$

$$
t_{t j}=t_{t j-1}-\frac{P_{h}\left(t_{j}\right) \cdot 3600+Q_{j}}{\rho_{j-1} V c_{p}}\left[{ }^{\circ} \mathrm{C}\right]
$$

where:

$t_{t j-1}$ - water temperature in buffer tanks in previous hour $\left[{ }^{\circ} \mathrm{C}\right]$,

$\mathrm{c}_{\mathrm{p}}$ - water specific heat $[\mathrm{kJ} /(\mathrm{kg} \cdot \mathrm{deg})]$.

Since $29^{\text {th }}$ February occurs once per four years length of $h_{j}$ is equal to one quarter hour on this particular day, in other days duration of $h_{j}$ equals 1 hour. Forasmuch as there is not any backup heater formula (3) reduces to

$$
S C O P_{n e t}=\frac{\sum_{j=1}^{5592} h_{j} P_{h}\left(t_{j}\right)}{\sum_{j=1}^{5592} \frac{h_{j} P_{h}\left(t_{j}\right)}{C O P_{b i n}\left(t_{j}\right)}} \quad[-]
$$

where 5592 is number of hours in a heating season containing a leap year, whereas $C O P_{b i n}\left(t_{j}\right)$ is linear interpolated from manufacturer data [4].

\subsection{The first variant}

Brine to water heat pump Vitocal 300-G Pro type BW 302.B120 was selected as heat generator in the first option. Its the most important technical data are written down in Table 1 .

To determine ground temperature Baggs [5] formula achieved for Australia continent was used. Therefore, the formula must have been adopted to Polish climatic conditions, which was done by Oleśkowicz-Popiel et. al [6]. Eventually, temperature profile in a ground is a function of depth $z$ and time $\tau$ :

$$
\begin{aligned}
t_{g}(z, \tau) & =\left(t_{m}+\Delta t_{m}\right)-1.07 k_{v} A_{s} \exp \left(-0.00031552 z a^{-0.5}\right) . \\
& \cdot \cos \left[\frac{2 \pi}{365}\left(\tau-\tau_{o}-0.018335 z a^{-0.5}\right)\right]
\end{aligned}
$$

The local constants in the formula (7) were achieved by Biernacka [7] and they are presented in Table 2 .

Temperature difference between ground and brine is based on a use experience in the location and it is equal to $5 \mathrm{deg}$. Since, ground temperature changes along borehole and it is dependent on time its mean value from ground level to depth $h=100 \mathrm{~m}$ at each hour in heating season is obtained from formula: 


$$
\bar{t}_{g}(\tau)=\frac{\int_{0}^{h} t_{g}(z, \tau) d z}{h}
$$

where $t_{g}(z, \tau)$ results from formula (7). The results of Eq. (8) are shown in Fig. 1 as "ground temperature". Hence, brine temperature, which is temperature of lower heat source, is 5 deg less than $\bar{t}_{g}(\tau)$ and it is presented in Fig. 1 as "brine temperature".

Table 1. Technical data of sized ground and water heat pump units, an extract from technical guide [4].

\begin{tabular}{|c|c|c|c|}
\hline & & $\begin{array}{c}\text { Vitocal 300-G } \\
\text { Pro type BW } \\
\text { 302.B120 }\end{array}$ & $\begin{array}{c}\text { Vitocal 300-W } \\
\text { Pro type WW } \\
\text { 302.B125 }\end{array}$ \\
\hline Output data to EN 14511 & & $\mathrm{B} 0 / \mathrm{W} 35$, & $\mathrm{W} 10 / \mathrm{W} 35$, \\
$5 \mathrm{~K} \mathrm{spread}$ & $\mathrm{K} \mathrm{spread}$ \\
\hline Rated heating output & $\mathrm{kW}$ & 117.2 & 112.1 \\
\hline Power consumption & $\mathrm{kW}$ & 24.4 & 18.3 \\
\hline Coefficient of performance (COP) & - & 4.8 & 6.1 \\
\hline Fluid in primary circuit & & brine & water \\
\hline
\end{tabular}

Table 2. The values of the constants in Baggs formula (7) at Białystok, cf. Biernacka [7].

\begin{tabular}{|c|c|c|c|}
\hline $\begin{array}{c}\text { difference between ground temperature below shallow } \\
\text { zone and average annual air temperature }\end{array}$ & $\Delta t_{m}$ & {$[\mathrm{deg}]$} & 2.2 \\
\hline vegetation coefficient & $k_{v}$ & {$[-]$} & 0.85 \\
\hline the amplitude of the annual air temperature & $A_{s}$ & {$[\mathrm{deg}]$} & 12.1 \\
\hline the soil thermal diffusivity & $a$ & {$\left[\mathrm{~m}^{2} / \mathrm{s}\right]$} & $6.00 \mathrm{E}-07$ \\
\hline the phase shift of the air temperature wave & $\tau_{o}$ & {$[\mathrm{~d}]$} & 22 \\
\hline average annual air temperature & $t_{m}$ & {$\left[{ }^{\circ} \mathrm{C}\right]$} & 7.407659 \\
\hline
\end{tabular}

\subsection{The second proposition}

One unit of Vitocal 300-W Pro WW 302.B125 is sized as alternative choice. Its the most important information is in Table 1. Just as previous one it must supply heat through a buffer tank and Kowalski [8] formula is applied to determine groundwater basin temperature

$$
t(z)=t_{m}+A+g_{g}(z-h) \quad\left[{ }^{\circ} C\right]
$$

where all the quantities are specified in Table 3. Since temperature below shallow zone is supposed to be constant all the year, achieved water temperature in groundwater basin is equal to $10.98^{\circ} \mathrm{C}$ and it is marked as "groundwater basin temperature" in Fig. 1.

Table 3. Data to calculation groundwater basin temperature.

\begin{tabular}{|c|l|c|c|}
\hline depth of shallow zone & $h$ & {$[\mathrm{~m}]$} & 5 \\
\hline depth of the groundwater basin & $z$ & {$[\mathrm{~m}]$} & 100 \\
\hline correction factor due to true altitude & $A$ & {$[-]$} & 0.856 \\
\hline geothermal gradient & $g_{g}$ & {$[\mathrm{deg} / \mathrm{m}]$} & $1 / 35$ \\
\hline
\end{tabular}

Forasmuch, we do not know in advance whether groundwater ingredients satisfy manufacturer's chemical requirements we consider a variant with separating heat exchanger (SHE) which would be built in the primary circuit in negative case. In that case water 
temperature of heat source in evaporator will be lower at $2{ }^{\circ} \mathrm{C}$ according to manufacturer data [4] (cf. "secondary water temperature" in Fig. 1).

\section{Results}

Coefficient of performance values in each hour during heating season are plotted in Fig. 2. $S C O P_{n e t}$ values resulting from Eq. (6) are written down in Fig. 2 as the labels.

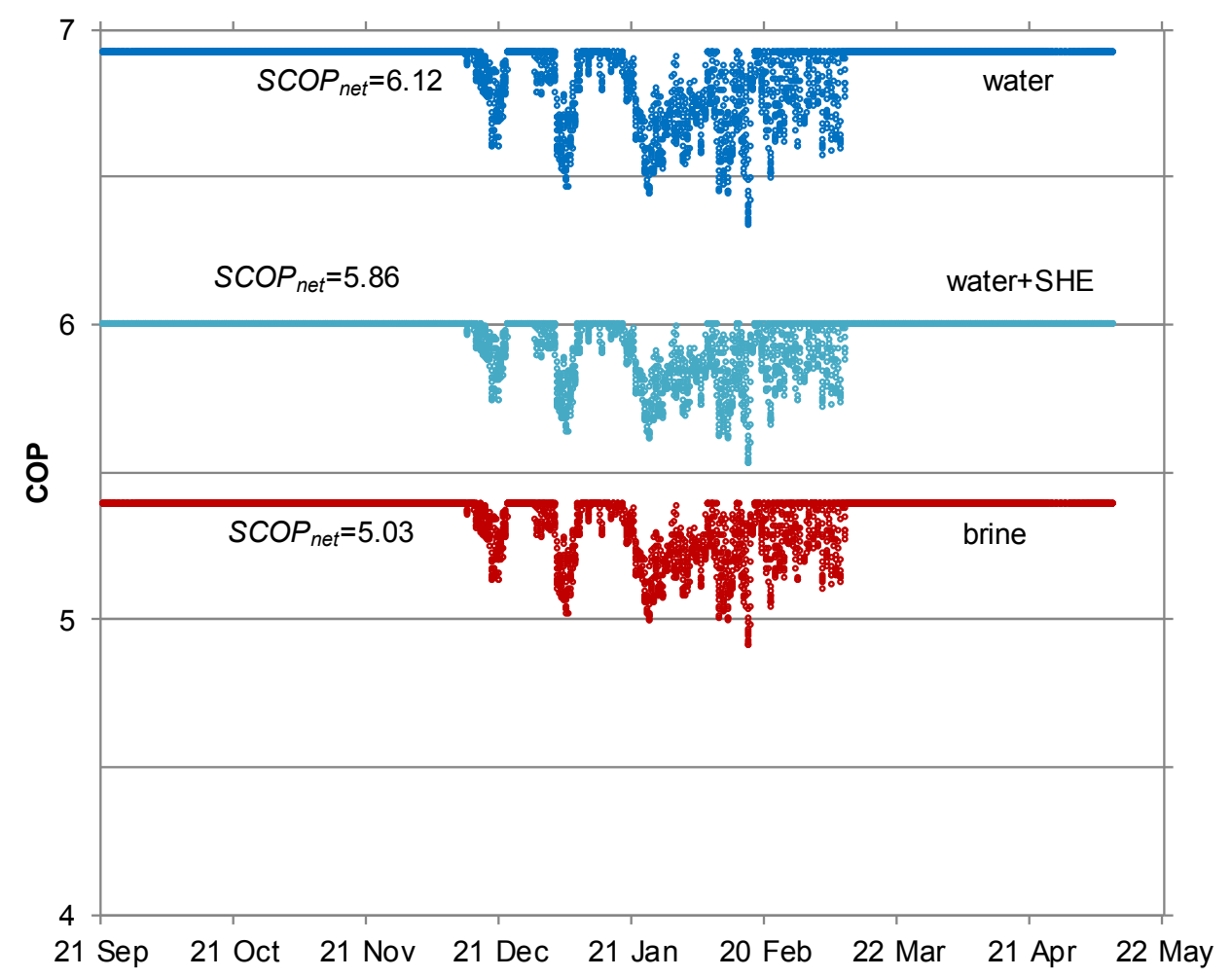

Fig. 2. $C O P_{b i n}$ interpolated from manufacturer data [4] and $S C O P_{n e t}$ obtained from Eq. (6) for three considered variants.

During heating season heat losses are function of external temperature because other factors are exactly or more less unchangeable, thus lower outside temperature causes bigger losses. Moreover lower outdoor temperature results in higher temperature in heating system. All these factors eventuate in lower values of bit $C O P$ and as a consequence bring about less value of $S C O P_{n e t}$. Heat pump is profitable when primary energy used during electricity production is less than heat transferred to a heating system. Taking into account product of the efficiencies of both power generation and electrical grid in Poland heat pump must achieve COP $=3.5$ at least (cf. Rubik [9], European Commission [10], and paper [11]). In all the investigated cases the requirement is fulfilled. SHE.

Higher $C O P$ values are in the case of water to water heat pump, regardless of possessing 


\section{Concluding remarks}

The major share in heat pump investment expenditures belongs to borehole drilling. If we assume specific heat extraction rate at $50 \mathrm{~W} / \mathrm{m}$ [4] we will need 19 U-tube ground heat exchangers at $100 \mathrm{~m}$ depth each. In the case of water heat pump despite of their rated heating output only two boreholes are needed the first bore for delivery well and the second one for return well. Hence, less interference with the environment is necessary to achieve the goal. Moreover, the fixed costs can be much lower when the groundwater source heat pump is applied. Furthermore, groundwater source heat pump is more effective as it results from the above computations. In conclusion, if there is a groundwater basin under assumed location water source heat pump should be considered as primary variant of heat generator for heating system in the buildings with design heat losses at about $100 \mathrm{~kW}$.

Meteorological data have been available thanks to a kindness of The Institute of Meteorology and Water Management - National Research Institute (IMGW-PIB). The scientific research were financed by Bialystok University of Technology as Dean's project at Department of HVAC Engineering S/WBiIŚ/4/2017.

\section{References}

1. Atmospheric CO2 from Continuous Air Samples at Mauna Loa Observatory, Hawaii, U.S.A. http://cdiac.ornl.gov/trends/co2/graphics/SIOMLOINSITUTHRU2008.JPG [12.05.2016]

2. European Council of the European Union, http://www.consilium.europa.eu/en/policies/climate-change/reform-eu-ets/ [23.05.2017]

3. The groundwater of the voivodeship capitals in Poland (Państwowy Instytut Geologiczny, Warszawa, 2007) (in Polish)

4. Viessmann, VITOCAL brine/water and water/water heat pumps, single and two-stage, 89 to $290 \mathrm{~kW}$, Technical guide, May 2013

5. S.A. Baggs, Sol. Energy 30, 4, 351-366 (1983)

6. C. Oleśkowicz-Popiel, J. Wojtkowiak, I. Prętka, FCEE 1, 2, 151-164 (2002)

7. B. Biernacka, Civil and Environmental Engineering 1, 5-9 (2010) (in Polish)

8. J. Kowalski, Hydrology with the basics of geology (UWP, Wrocław, 2007) (in Polish)

9. M. Rubik, COW 6, 3-6 (2008) (in Polish).

10. 2013/114/EU: Commission Decision of 1 March 2013 establishing the guidelines for Member States on calculating renewable energy from heat pumps from different heat pump technologies pursuant to Article 5 of Directive 2009/28/EC of the European Parliament and of the Council

11. A. Gajewski, J. Siergiejuk, K. Szulborski, Energy Build. 65, 197-204 (2013) 